Journal of Southeast Asian

\title{
Appendix H: Focus Group Summary of the Cambodian and Lao Student Union
}

Kanara Ty

San Francisco State University, kanara@gmail.com

\section{Recommended Citation}

Ty, Kanara (2011) "Appendix H: Focus Group Summary of the Cambodian and Lao Student Union," Journal of Southeast Asian American Education and Advancement: Vol. 6 : Iss. 1, Article 9.

DOI: $10.7771 / 2153-8999.1025$

Available at: https://docs.lib.purdue.edu/jsaaea/vol6/iss1/9

This document has been made available through Purdue e-Pubs, a service of the Purdue University Libraries. Please contact epubs@purdue.edu for additional information.

This is an Open Access journal. This means that it uses a funding model that does not charge readers or their institutions for access. Readers may freely read, download, copy, distribute, print, search, or link to the full texts of articles. This journal is covered under the CC BY-NC-ND license. 


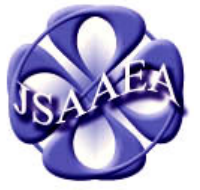

Volume 6 (2011)
Journal of Southeast Asian American

Education \& Advancement

WWW.JSAAEA.org
A peer-reviewed

scholarly journal

published by the

National Association

for the Education \&

Advancement of

Cambodian, Laotian,

and Vietnamese

Americans (NAFEA)

\title{
Southeast Asian American Education 35 Years After Initial Resettlement: Research Report and Policy Recommendations
}

Conference Report of the National Association for the Education and Advancement of Cambodian, Laotian, and Vietnamese Americans

\section{APPENDIX H \\ Focus Group Summary of the Cambodian and Lao Student Union}

\author{
Kanara Ty \\ San Francisco State University
}

The discussion with Cambodian American students at San Francisco State University brought up three main issues within their educational experiences: (1) Curriculum/Testing, (2) Administrative Support and Mentoring, and (3) Identity and Cultural Issues.

\section{Curriculum/Testing}

The main issue that revolved this area was course relevance to students. Many students in the group felt that schools focused on students succeeding during state testing. There was a huge pressure on student success on these statewide examinations because of the No Child Left Behind Act. Students also mentioned it was a huge pressure for teachers to "teach the test" to the students and making sure they performed well on these examinations.

Students were well aware of the fact that these examinations were not accurate of how well they could do on subjects - it only measured how well prepared they were for the actual test. A student mentioned, "It counted towards the school's grade, but not our grades." Many students also discussed that they knew of peers purposely choosing not to do well as an act of rebellion against the state testing.

\footnotetext{
() SORERIIGHISRESEREED Readers are free to copy, display, and distribute this article, as long as the work is attributed to the author(s) and the Journal of Southeast Asian American Education \& Advancement, it is distributed for noncommercial purposes only, and no alteration or transformation is made in the work. More details of this Creative Commons license are available at $\mathrm{http}: / /$ creativecommons.org/licenses/by-nc-nd/3.0/. All other uses must be approved by the author(s) or JSAAEA.
} 
Many Cambodian American students in the organization reported not knowing their own history (such as their family refugee history following the Cambodian Genocide) until they enrolled in an Asian American Studies/Ethnic Studies course at the university. Students highly believe that that these relevant courses helped them gain a better sense of self and propelled a more politicized identity formation.

\section{Administrative Support and Mentoring}

A weak support system and poor communication are two of the main issues within administrators at school. Only a fourth of the Cambodian American students within the organization reported having a Southeast Asian administrator during their K-12 education. Some students had stated that they would have felt better understood and easier to approach if there were an authoritative figure at the school that had the same (or similar) ethnic background and experience. Some students felt that if there was a Southeast Asian administrator, their voices could be heard and they would not feel as marginalized on campus.

To further extend the weak support system within administrators, students felt they did not have any mentorship. As part of a smaller ethnic group (and nearly nonexistent), many students felt they needed more (or better) counseling services. These counseling services would help them get through their personal issues and goals, such as academic counseling to move on to higher education.

Many students also felt their parents were disconnected to the school because of the language barriers. Many students stated their parents could not communicate with administrators because there was no one available to translate (not many students could translate for their parents). Students wished for administrators who could speak the language - or even have someone on campus who would be able to translate. Translated materials would also have been helpful.

\section{Identity and Cultural Issues}

As a marginalized ethnic group, the Cambodian American students in the organization feel invisible on campus. While some students come from cities with large Cambodian populations, there were many students who were also the only Cambodian American student within their schools prior to college. The students who came from cities with very little Cambodians had experiences with peers not knowing the Cambodian ethnic identity. Regardless of where they came from, most of the students reported experiencing racism, whether it was derogatory language or violence. Students felt that there's little awareness on Cambodian Americans and that was why many students had negative experiences growing up Cambodian American.

As reported above, many of the students have little to no Khmer speaking ability. Their low speaking abilities resulted in poor communication with their non English-speaking parents, especially when it came to school related matters. Often, this resulted in miscommunication over multiple issues, such as parent/teacher meetings and examinations. Many students report not having opportunities to learn to speak Khmer, as 
their parents were not able to teach them any speaking, reading, or writing skills (as well as no opportunities available in the community).

Finally, less than fourth of the Cambodian American students had a strong sense of self and connection to their Cambodian American identity. These particular subset felt their strong connection to Cambodian American identity because they were either enrolled in Khmer language or Classical Khmer dance classes that were taught in the community center or temple. These students also came from larger Cambodian populations such as Long Beach or Fresno (in California).

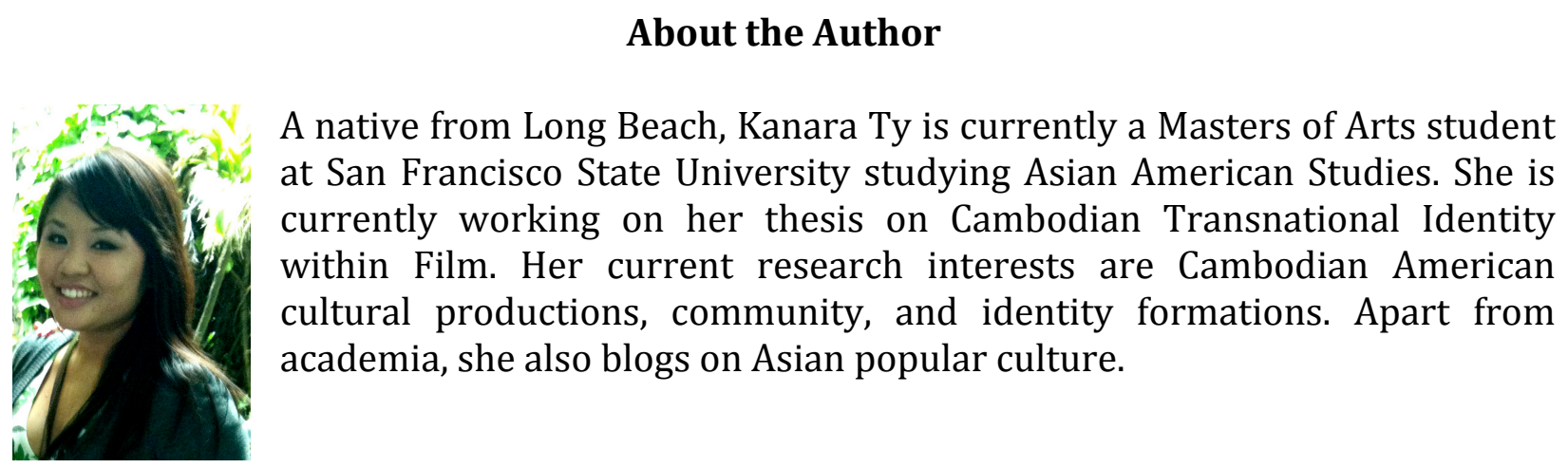

